\title{
EFFECTS OF TRADE LIBERALIZATION ON EXPORTS, IMPORTS AND TRADE BALANCE IN PAKISTAN: A TIME SERIES ANALYSIS
}

\author{
Muhammad Zakaria*
}

\begin{abstract}
:
Using time series data, the paper empirically analyzes the effects of trade liberalization on exports, imports and trade balance in Pakistan for the period 1981/82 to 2007/08. It concludes that trade liberalization stimulates both exports and imports with the effect being greater on latter than on former thereby worsening the trade balance. Other variables, that is, real exchange rate, domestic and foreign incomes, terms of trade and foreign exchange market distortions affect exports, imports and trade balance in the theoretically expected directions. Inclusion of interaction terms indicate that liberalization stimulates both price and income elasticities of exports, imports and trade balance. These results have important policy implications for degree of trade liberalization in Pakistan.
\end{abstract}

Keywords: trade liberalization, exports, imports, trade balance

JEL Classification: C13, C22, F13

\section{Introduction}

Over the past sixty years, particularly in the last three decades, one of the pronounced characteristics of the world economy has been that developing countries have experienced rapid trade liberalization either unilaterally or as part of multilateral initiatives with the World Bank, WTO and the IMF. The simplification of import procedures, the reduction or elimination of quantitative restrictions and the rationalization of the tariff structures are the most widespread reforms. These trade liberalization reforms have important implications for exports, imports and trade balance of the developing countries. Many developing countries are still reluctant to liberalize their economies as it will deteriorate their trade balance as imports will increase more than exports after liberalization. ${ }^{1}$

Theoretical literature has developed mainly three approaches to explore the effect of trade liberalization on trade balance of an economy namely the elasticity approach, the absorption approach and the monetary approach. The elasticity approach is mainly concerned with exploring the effects of trade liberalization on export and import price elasticities. However, this approach relegates other aspects of trade liberalization that

* COMSATS Institute of Information Technology, Islamabad, Pakistan (mzakaria80@hotmail.com)

1 Loss of tariff revenues is another reason for not liberalizing the economy. 
do not involve price changes. According to the absorption approach the effect of trade liberalization will depend on how real income is affected relative to real absorption. Finally, in the monetary approach, the outcome of trade liberalization depends on how the real demand for money changes relative to the real supply. Previously, the so-called 'intertemporal approach' was also used to examine the effects of trade liberalization policies on trade balance. This approach explores the intertemporal impacts of transitory and permanent changes in both export and import tariffs on trade balance. The main problem with the intertemporal model is that it is very sensitive to the underlying assumptions. Ostry and Rose (1992) conclude that the effect of trade liberalization on trade balance is equivocal as the effect depends on the behaviour of exchange rates, on the significance of various elasticities, the degree of capital mobility and whether the tariff shock is believed as temporary or permanent.

Empirically the effect of trade liberalization on exports, imports and trade balance remainedmixed. Somestudieshaveshown positiveeffectoftradeliberalizationonexports (Bleaney, 1999; Weiss, 1992; Ahmed, 2000; Santos-Paulino, 2002a; Ju et al., 2010), whereas some other studies have found little evidence of such a relationship (Greenaway and Sapsford, 1994; Jenkins, 1996; Agosin, 1991; Shafaedin, 1994). Studies generally find positive impact of trade liberalization on imports (Melo and Vogt, 1984; Mah, 1999; Bertola and Faini, 1991; Santos-Paulino, 2002b; Ju et al., 2010). Retrospect empirics have also documented that imports increase comparatively quickly to trade liberalization than exports, thereby resulting in transitory trade imbalances (Bertola and Faini, 1991; Khan and Zahler, 1985; Krueger, 1978; Santos-Paulino, 2004; Santos-Paulino and Thirlwall, 2004). Other studies find insignificant or mixed outcomes regarding the effect of trade liberalization on trade balance ( $\mathrm{Ju}$ et al., 2010; Ostry and Rose, 1992). This asymmetric impact of liberalization on exports, imports and trade balance is due to the fact that studies differ in their time periods, estimation techniques, data sets, theoretical models and trade liberalization measures. Furthermore, there are limitations in the econometric implications of the models (as most of the studies overlook the issue of simultaneity). Almost all of the previous empirical studies focused on cross-country analysis and overlooked the time-series framework. Therefore a single country case study is called for. This is exactly what the present study is meant to do.

During the early 1980s Pakistan was persuaded to implement trade reforms along with structural adjustment policies, enforced by the IMF, the WB and other international institutions, as an imperative step towards free-market economy. To acquire financial support Pakistan showed grave proclivity for free-market economy and conceded all kinds of conditionalities imposed by the world organizations. Consequently, during the mid 1980s trade reforms were implemented and trade liberalization was institutionalized. It involved policy measures that called for reducing the level of tariffs, removing quantitative restrictions, introducing uniformity in tariff structures and levels, and reducing the severity of other kinds of taxes on international trade. This process of trade liberalization continued in the 1990s and early twenties as well. 
These trade reforms are expected to increase both exports and imports. However, its effect on trade balance is ambiguous as it depends on the relative impacts on exports and imports and its effects on traded goods prices. The objective of this study is to examine the effects of trade liberalization on exports, imports, and trade balance in Pakistan for the period $1981 / 82$ to $2007 / 08$. This study is expected to be an important attempt to address this issue in a technical, systematic and rigorous way for Pakistan (a developing country) by applying standard estimation techniques as no such study has been conducted for Pakistan previously.

The rest of the paper is organized as follows. The following section provides the process of trade liberalization in Pakistan. Section 3 constructs theoretical models. Section 4 provides the empirical results along with their interpretation. Final section concludes the paper.

\section{Trade Liberalization in Pakistan}

\subsection{Historical review}

In 1947, Pakistan's economy was based on agriculture and had only a few industrial units. To protect its nascent industrial units from international competition Pakistan followed the restricted trade policy. However, in the late 1950s Pakistan introduced measures to liberalize its economy for foreign trade. This liberalization process was retarded in the late 1960s as foreign aid was curtailed after the war with India in 1965, coupled with consecutive bad harvests. In December 1971, after the cessation of East Pakistan (now Bangladesh) from West Pakistan (now Pakistan), Pakistan once again started to liberalize its foreign trade to find alternative markets for traded items. Among them devaluation of Pak-rupee, deletion of the export bonus scheme, and elimination of restrictive licensing were the most important policies. However, in late seventies, when oil price shocks occurred, imports were again restricted due to limited foreign exchange reserves. In the early 1980s government started a slow and cautious process of trade liberalization. In January 1982, shift from fixed to a managed floating exchange rate system and the removal of fixed parity of the rupee from the US dollar were by far the most important measures undertaken by the government to encourage exports. To increase imports, most of the tariff rates were cut down, the numbers of tariff slabs were reduced and a uniform sales tax was applied across all commodities.

In the mid 1980s government started a comprehensive program of trade liberalization in an agreement with the IMF and the World Bank. The significant steps include reducing tariffs, elimination of banned list and conversion of Industrial Incentives Reform Cell into Tariff Commission. Further, Pakistan continued the policy of flexible exchange rate system, which helped to reduce anti-export bias. To promote export, several other measures were also undertaken, which include elimination of export duties, refund of sales tax, duty drawback scheme, export credit guarantee scheme and export finance schemes. Pakistan had achieved a neutral trade regime to a considerable 
extent in the nineties as a result of trade reforms. In $21^{\text {st }}$ century Pakistan continues the policy of trade liberalization. For this purpose government is following the tariff rationalization policy, which is based on the concept of minimal tariff and non-tariff barriers and the market based exchange rate system which is in accordance with the industrial policy goals.

\subsection{Exports, imports and trade duty rates}

Export and import duty rates were high during the import substitution industrialization period as Figure 1 reveals because Pakistan did not have enough foreign exchange reserves, and workers remittances were also low, to import high quantity of intermediate capital goods for industrialization. ${ }^{2}$ Moreover, Pakistan had not attracted enough foreign direct investment to offset the trade deficit. During the early 1960s duties were somewhat reduced to follow a liberal trade policy but after the war with India in 1965 and the resulting loss of precious foreign exchange, high duties were again levied on imports. During the 1970s and until the mid-1980s import duties remained high and therefore trade (average of export plus import) duties were also high although the export duties were low. After the mid-1980s Pakistan embarked on the process of trade liberalization and reduced import duties while the export duties were more or less altogether abolished. During the 2000s Pakistan further cut its tariffs down as Pakistan's foreign exchange position also became stable due to the substantial inflow of workers' remittances after the event of September 11, 2001.

Figure 1

\section{Exports, Imports and Trade Duty Rates (\%)}

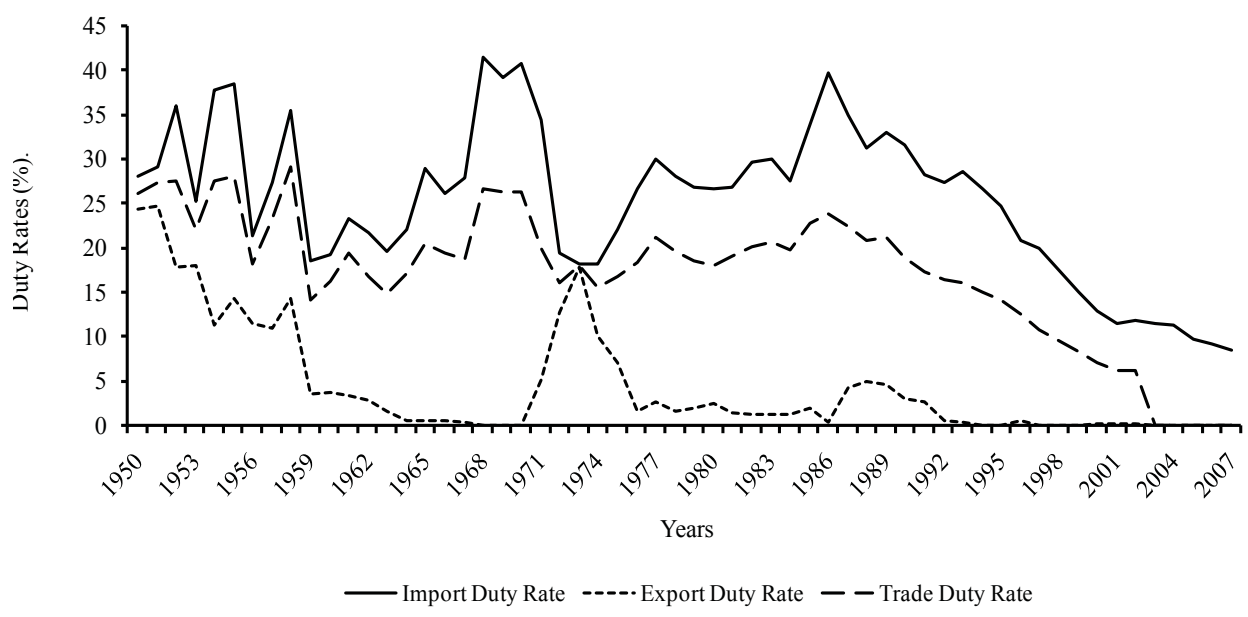

2 Another important reason for the implementation of highly restrictive trade policy was that Pakistan had no industries to levy tax upon. Therefore, Pakistan heavily relied upon trade duties - an important component of indirect taxes - for revenue generations to carry on its development projects. 


\subsection{Exports, imports and trade deficit}

Due to highly restrictive commercial policy that Pakistan followed, particularly in its first two and a half decades, both exports and imports remained very low as Figure 2 indicates. Another reason for the low levels of exports and imports was that before 1971 (the united) Pakistan was a large country both in terms of area and population and, therefore, needed limited dependence on international trade as both wings had high levels of trade with each other. However, after the separation of East Pakistan from West Pakistan in 1971, Pakistan's trade with Bangladesh was now considered as foreign trade and many goods which had earlier been sent to East Pakistan were successfully diverted into other foreign markets. As a result, the levels of both exports and imports increased. After the mid 1980s when Pakistan opened up its economy for international trade, the level of both exports and imports surged mainly due to the reduction of maximum import tariff rates, along with rescinding of non-tariff barriers, elimination of the taxes on exports and the implementation of managed floating exchange rate system.

Figure 2

Exports, Imports and Trade Deficit (\$ billions)

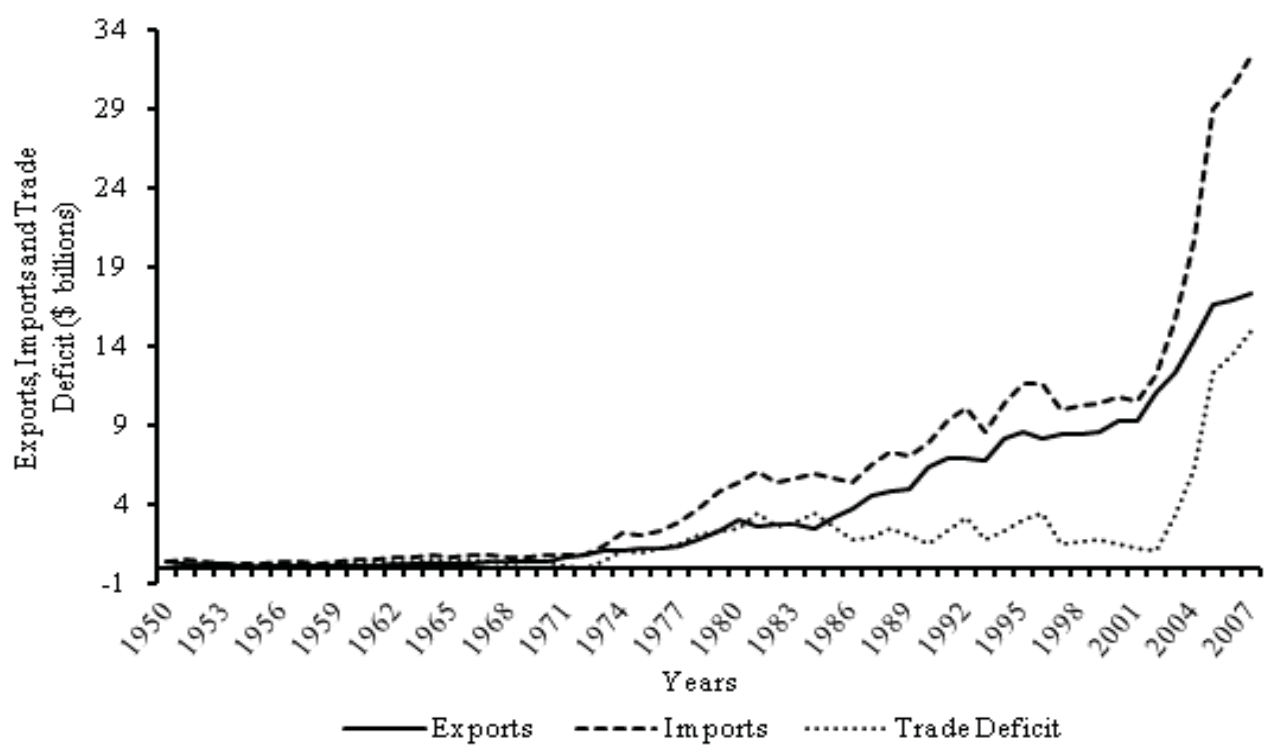

Trade liberalization, however, has increased imports more than exports, which has created high levels of trade deficits, as Figure 2 indicates. This high level of trade deficit persists throughout the period. Trade balance delivered surplus only twice, for first time in 1950 when due to Korean War Pakistan's exports increased and its trade balance went into surplus. Trade balance turned into surplus for second time in 1972 when 
Pakistan devalued its currency by 131 percent. In 1973, however, there was an oil price shock and worldwide inflationary pressures caused deterioration in Pakistan's terms of trade. Accordingly, the increase in imports far outstripped the increase in exports and trade deficit persisted throughout the rest of the decade. Even after liberalization episodes of the late 1980s imports increased more than exports, thereby leaving trade balance in deficit. In the early 2000 s oil prices surged worldwide, therefore trade deficit further increased.

\section{Analytical Framework ${ }^{3}$}

\subsection{Trade liberalization and exports}

The present study analyses the impact of trade liberalization on exports using export demand function theory. Traditionally, the export demand of a country is presumed to depend primarily on international competitiveness measured by relative prices at home and abroad denominated in common currencies, and the world demand. If the relative price and the world income elasticities are assumed constant, the export function can be expressed as

$$
X_{t}=\mathrm{A}\left(R E R_{t}\right)^{\alpha_{1}}\left(Y_{t}^{*}\right)^{\alpha_{2}}
$$

where $X_{t}$ is domestic export, $R E R_{t}$ is real exchange rate ${ }^{4}$, and $Y_{t}^{*}$ is foreign income level. After taking natural logarithm we get

$$
\ln \left(X_{t}\right)=\ln (\mathrm{A})+\alpha_{1} \ln \left(R E R_{t}\right)+\alpha_{2} \ln \left(Y_{t}^{*}\right)
$$

By taking the derivative on both sides of the above equation with respect to time we can see how the growth rate of export is related to the growth rate of the relative prices and the world income.

$$
\frac{\dot{X}_{t}}{X_{t}}=\frac{\dot{\mathrm{A}}}{\mathrm{A}}+\alpha_{1}\left(\frac{R \dot{E} R_{t}}{R E R_{t}}\right)+\alpha_{2}\left(\frac{\dot{Y}_{t}^{*}}{Y_{t}^{*}}\right)
$$

In empirical form, using lower-case letters, the above equation can be written as

$$
x_{t}=\alpha_{0}+\alpha_{1}\left(\operatorname{rer}_{t}\right)+\alpha_{2}\left(y_{t}^{*}\right)+\mu_{t}
$$

where $x_{t}\left(=\dot{X}_{t} / X_{t}\right)$ is the growth rate of real exports, $\operatorname{rer}_{t}\left(=R \dot{E} R_{t} / R E R_{t}\right)$ is the growth rate of real exchange rate, and $y_{t}^{*}\left(=\dot{Y}_{t}^{*} / Y_{t}^{*}\right)$ is the growth rate of world income. Further, $\alpha_{0}(=\dot{\mathrm{A}} / \mathrm{A})=0$ is the assumed restriction. Basically, $\alpha_{0}$ is a constant term which may pick up supply-side factors such as technological shocks. $\alpha_{1}$ is the

3 This section leans upon Santos-Paulino and Thirlwall (2004). See Ju et al. (2010) for recent application of such types of theoretical models.

4 Throughout this study exchange rate is taken in direct quote, that is, domestic currency per unit of foreign currency where an increase (decrease) in exchange rate indicates depreciation (appreciation) of the local currency. 
price elasticity of demand for exports and $\alpha_{2}$ is the income elasticity of demand for exports and both are assumed to be positive i.e. $\alpha_{1}>0$ and $\alpha_{2}>0$. Finally, $\mu_{\mathrm{t}}$ is white noise stochastic error term with usual properties i.e. $\mu_{t} \sim N\left(0, \sigma^{2}\right)$.

By introducing the trade liberalization variables in the export demand equation we will get the following augmented version of equation (3b).

$$
x_{t}=\alpha_{0}+\alpha_{1} \operatorname{rer}_{t}+\alpha_{2} y_{t}^{*}+\alpha_{3} T R F_{t}^{x}+\alpha_{4} D_{t}+\mu_{t}
$$

where $T R F_{t}^{x}$ is average export tariff rate and $D_{t}$ is a liberalization dummy variable that takes the value of 1 for the period in which significant liberalization took place and zero otherwise. The coefficient of $T R F_{t}^{x}$ is expected to be negative $\left(\alpha_{3}<0\right)$ while the coefficient of $D_{t}$ is expected to be positive $\left(\alpha_{4}>0\right)$.

Trade liberalization is also likely to affect both price and income elasticities of exports. For example, liberalization may increase the sensitivity of exports to price and income changes by allowing producers to move resources into traded goods sector by generating structural change and creating allocative efficacy. These interaction effects are captured by introducing two interaction terms in the above equation. Now equation (4) can be written as

$$
x_{t}=\alpha_{0}+\alpha_{1} r e r_{t}+\alpha_{2} y_{t}^{*}+\alpha_{3} T R F_{t}^{x}+\alpha_{4} D_{t}+\alpha_{5} D_{t} \operatorname{rer}_{t}+\alpha_{6} D_{t} y_{t}^{*}+\mu_{t}
$$

The coefficients of both $D_{t}$ rer $_{t}$ and $D_{t} y_{t}{ }^{*}$ are expected to be positive i.e. $\alpha_{5}>0$ and $\alpha_{6}>0$. Basically, the coefficient of the shift dummy $\left(D_{t}\right)$ should be considered as the 'pure' liberalization effect on export performance, independent of the effect of liberalization working through its impact on relative price changes or growth performance.

To check the robustness of the results the following augmented versions of export growth equations (4) and (5) will also be estimated.

$$
\begin{aligned}
x_{t}=\alpha_{0}+\alpha_{1} \operatorname{rer}_{t} & +\alpha_{2} y_{t}^{*}+\alpha_{3} \operatorname{TRF}_{t}^{x}+\alpha_{4} D_{t}+\alpha_{5} \text { tot }_{t}+\alpha_{6} \text { FEMD }_{t}+\mu_{t} \\
x_{t}=\alpha_{0}+\alpha_{1} \operatorname{rer}_{t} & +\alpha_{2} y_{t}^{*}+\alpha_{3} T R F_{t}^{x}+\alpha_{4} D_{t} \\
& +\alpha_{5} D_{t} \operatorname{rer}_{t}+\alpha_{6} D_{t} y_{t}^{*}+\alpha_{7} \text { tot }_{t}+\alpha_{8} \text { FEMD }_{t}+\mu_{t}
\end{aligned}
$$

where tot $_{t}$ denotes growth rate of terms of trade and $F E M D_{t}$ represents foreign exchange market distortions (proxied by black market premium). As terms of trade increases exports will fall because export prices are increasing relatively more than import prices. Thus, tot $_{t}$ is expected to have a negative effect on exports. High foreign exchange market distortions will increase smuggling and will decrease exports. Thus, $F E M D_{t}$ is also expected to have a negative effect on exports. 


\subsection{Trade liberalization and imports}

Like export demand function, we have considered a standard import demand function. Following the same methodology as in export demand function, we have modelled the following import demand function.

$$
m_{t}=\beta_{0}+\beta_{1} \operatorname{rer}_{t}+\beta_{2} y_{t}+v_{t}
$$

where $m_{t}$ is the growth rate of real imports, $r e r_{t}$ is the growth rate of real exchange rate, $y_{t}$ is the growth rate of domestic output, $\beta_{0}=0$ is the assumed restriction; in essence, $\beta_{0}$ is a constant term which may absorb supply side shocks such as technological spillovers as in the export growth equation. The parameters $\beta_{1}(<0)$ and $\beta_{2}(>0)$ are price and income elasticities, respectively. Finally, $v_{t}$ is white noise stochastic error term with usual properties i.e. $v_{t} \sim N\left(0, \sigma^{2}\right)$.

To check the effects of trade liberalization on import growth we will estimate the following equation.

$$
m_{t}=\beta_{0}+\beta_{1} \operatorname{rer}_{t}+\beta_{2} y_{t}+\beta_{3} T R F_{t}^{m}+\beta_{4} D_{t}+v_{t}
$$

where $T R F_{t}^{m}$ is average import tariff rates and $D_{t}$ is the liberalization dummy variable. The coefficient of $T R F_{t}^{m}$ is presumed to be negative $\left(\beta_{3}<0\right)$ while the coefficient of $D_{t}$ is expected to be positive $\left(\beta_{4}>0\right)$.

By introducing the interaction terms in the import equation we will get the following augmented version of Equation 9.

$$
m_{t}=\beta_{0}+\beta_{1} r e r_{t}+\beta_{2} y_{t}+\beta_{3} T R F_{t}^{m}+\beta_{4} D_{t}+\beta_{5} D_{t} \mathrm{rer}_{t}+\beta_{6} D_{t} y_{t}+v_{t}
$$

As liberalization proceeds, the price elasticity of import demand increases since the ability to substitute domestic production for imports (import substitution) becomes easier (Melo and Vogt, 1984). Therefore, the coefficient of $D_{t}$ rer $_{t}$ is assumed to be negative $\left(\beta_{5}<0\right)$. Further, as the degree of import liberalization enlarges, the income elasticity of demand also increases, i.e. the removal of trade controls will tend to increase the income elasticity automatically (Melo and Vogt, 1984). Therefore, the coefficient of $D_{t} y_{t}$ is assumed to be positive $\left(\beta_{6}>0\right)$. Basically, the coefficient of the shift dummy $\left(D_{t}\right)$ should be considered as the 'pure' liberalization effect on imports, independent of the effect of liberalization working through its impact on relative price changes or growth performance. To check the robustness of the results the following augmented versions of import growth equations (9) and (10) will also be estimated.

$$
\begin{aligned}
& m_{t}=\beta_{0}+\beta_{1} \text { rer }_{t}+\beta_{2} y_{t}+\beta_{3} T R F_{t}^{m}+\beta_{4} D_{t}+\beta_{5} \text { tot }_{t}+\beta_{6} F E M D_{t}+v_{t} \\
& m_{t}=\beta_{0}+\beta_{1} \mathrm{rer}_{t}+\beta_{2} y_{t}+\beta_{3} \operatorname{TRF}_{t}^{m}+\beta_{4} D_{t} \\
& +\beta_{5} D_{t} \text { rer }_{t}+\beta_{6} D_{t} y_{t}+\beta_{7} \text { tot }_{t}+\beta_{8} \text { FEMD }_{t}+v_{t}
\end{aligned}
$$


where as before tot $_{t}$ is growth rate of terms of trade and $F E M D_{t}$ is foreign exchange market distortions. As terms of trade increases imports will increase as export prices are increasing relatively more than import prices. Thus, tot $_{t}$ is expected to have a positive effect on imports. With the increase in foreign exchange market distortions, imports will fall. Thus, $F E M D_{t}$ is expected to have a negative effect on imports.

\subsection{Trade liberalization and trade balance}

We specify trade balance as the ratio of value of exports to value of imports in order to facilitate working with logs and growth rates (see Pacheco-López, 2003, 2005). Mathematically

$$
T B_{t}=\left(\frac{P_{t}^{X} X_{t}}{P_{t}^{M} M_{t}}\right)
$$

where $T B_{t}$ is trade balance, and $P_{t}^{X}\left(P_{t}^{M}\right)$ and $X_{t} M_{t}$ describe export (import) prices and volume of exports (imports), respectively. By taking natural logarithm and differentiating with respect to time the above equation can be expressed as

$$
t b_{t}=\left(x_{t}-m_{t}\right)+\left(p_{t}^{x}-p_{t}^{m}\right)
$$

where $t b_{t}$ is growth rate of trade balance, while $x_{t}\left(m_{t}\right)$ and $p_{t}^{x}\left(p_{t}^{m}\right)$ is growth rate of volume of exports (imports) and export (import) prices, respectively. The term in second parenthesis of the above equation, which is the difference between growth rate of export and import prices $\left(p_{t}^{x}-p_{t}^{m}\right)$, is nothing but the growth rate of terms of trade $\left(\right.$ tot $\left._{t}\right)$. By substituting equations (4) and (9), which define the growth rate of exports and imports, respectively, in the above equation and after some manipulation we will get the following equation.

$$
\begin{aligned}
t b_{t}=\lambda_{0} & +\lambda_{1} r e r_{t}+\lambda_{2} y_{t}^{*}+\lambda_{3} y_{t} \\
& +\lambda_{4} T R F_{t}^{x}+\lambda_{5} T R F_{t}^{m}+\lambda_{6} D_{t}+\lambda_{7} \text { tot }_{t}+v_{t}
\end{aligned}
$$

where $\lambda_{0}\left(=\alpha_{0}-\beta_{0}\right)=0$ and $\lambda_{7}=1$ are the assumed restrictions. Basically, $\lambda_{0}$ captures the impacts of technological diffusion and spillovers on trade balance.

The theoretically expected effect of real exchange rate $\mathrm{rer}_{t}$ on trade balance is positive (Pacheco-Lopez, 2003, 2005). Since $\alpha_{1}>0$ and $\beta_{1}<0, \lambda_{1}\left[=\alpha_{1}-\left(-\beta_{1}\right)\right]>0$. Foreign income $\left(y_{t}{ }^{*}\right)$ is expected to improve trade balance while domestic income $\left(y_{t}\right)$ is to deteriorate it. Thus $\lambda_{2}\left(=\alpha_{2}\right)$ is expected to bear a positive sign while $\lambda_{3}\left(=-\beta_{2}\right)$ to bear a negative sign. Export tariffs $\left(T R F_{t}^{x}\right)$ will deteriorate trade balance while import tariffs $\left(T R F_{t}^{m}\right)$ will improve it. Thus, the signs of $\lambda_{4}\left(=\alpha_{3}\right)$ and $\lambda_{5}\left(=-\beta_{3}\right)$ are expected to be negative and positive, respectively. The impact of liberalization dummy $\left(D_{t}\right)$ on trade balance is ambiguous as it is depends upon whether liberalization leads to faster growth in exports or imports. So, the theoretically expected sign of $\lambda_{6}\left(=\alpha_{4}-\beta_{4}\right)$ is undetermined. Terms of trade $\left(\right.$ tot $\left._{t}\right)$ is an important descriptive variable to be considered in determining trade balance as fluctuations in prices of exports and imports influence the money value of trade flows independent of 
trade liberalization (Santos-Paulino, 2004). Basically, in our model terms of trade will positively affect trade balance as we have restricted the coefficient of terms of trade equals to unity by assumption i.e. $\lambda_{7}=1$. Finally, $v_{t}$ is white noise stochastic error term with usual properties, i.e. $v_{t} \stackrel{i i}{\sim} N\left(0, \sigma^{2}\right)$.

Since liberalization also influences trade balance by affecting relative prices and domestic and foreign income growth rates, some of the effects of liberalization on trade balance will be considered by introducing some interaction terms. With the introduction of interaction terms equation (15) can be written as

$$
\begin{aligned}
t b_{t}=\lambda_{0} & +\lambda_{1} \operatorname{rer}_{t}+\lambda_{2} y_{t}^{*}+\lambda_{3} y_{t}+\lambda_{4} T R F_{t}^{x}+\lambda_{5} T R F_{t}^{m} \\
& +\lambda_{6} D_{t}+\lambda_{7} \operatorname{tot}_{t}+\lambda_{8} D_{t} \operatorname{rer}_{t}+\lambda_{9} D_{t} y_{t}^{*}+\lambda_{10} D_{t} y_{t}+v_{t}
\end{aligned}
$$

Since the theoretically expected effect of real exchange rate on trade balance is positive, the sign of $\lambda_{8}$ is positive. Since $\alpha_{5}>0$ and $\beta_{5}<0, \lambda_{8}\left[=\alpha_{5}-\left(-\beta_{5}\right)\right]>0$. The interaction term between liberalization and domestic growth $\left(D_{t} y_{t}\right)$ takes the value of $y_{t}$ post-liberalization and zero otherwise. The coefficient of this variable $\lambda_{10}\left(=-\beta_{6}\right)$ is presumed to have a negative sign as domestic income after trade liberalization would have raised the imports, thereby deteriorating the trade balance. Following the similar intuition, a positive sign is expected for the coefficient $\lambda_{9}\left(=\alpha_{6}\right)$. Thus the coefficient $\lambda_{6}$ captures the 'pure' liberalization effects on trade balance while the coefficients $\lambda_{9}$ and $\lambda_{10}$ shows the effects of liberalization on trade balance working through foreign and domestic incomes, respectively.

For comparison purpose the following augmented versions of trade balance growth equations will also be estimated.

$$
\begin{aligned}
t b_{t}=\lambda_{0}+\lambda_{1} \operatorname{rer}_{t} & +\lambda_{2} y_{t}^{*}+\lambda_{3} y_{t}+\lambda_{4} T R F_{t}^{x} \\
& +\lambda_{5} T R F_{t}^{m}+\lambda_{6} D_{t}+\lambda_{7} \text { tot }_{t}+\lambda_{8} F E M D_{t}+v_{t} \\
t b_{t}=\lambda_{0} & +\lambda_{1} \operatorname{rer}_{t}+\lambda_{2} y_{t}^{*}+\lambda_{3} y_{t}+\lambda_{4} T R F_{t}^{x}+\lambda_{5} T R F_{t}^{m} \\
& +\lambda_{6} D_{t}+\lambda_{7} \operatorname{tot}_{t}+\lambda_{8} D_{t} \operatorname{rer}_{t}+\lambda_{9} D_{t} y_{t}^{*}+\lambda_{10} D_{t} y_{t}+\lambda_{11} \text { FEMD }_{t}+v_{t}
\end{aligned}
$$

In these equations the effect of terms of trade $\left(\right.$ tot $\left._{t}\right)$ on trade balance is ambiguous because $\lambda_{7}$ is no more equal to unity. In equation (17) $\lambda_{7}=1+\alpha_{5}-\beta_{5}$, and in equation (18) $\lambda_{7}=1+\alpha_{7}-\beta_{7}$. As terms of trade increase, export prices will increase relatively more than import prices, hence exports will decrease and imports will increase. Therefore, it is likely that with lower exports and higher imports the trade balance will get worse. However, it relies on Marshall-Lerner condition. If the Marshall-Lerner condition is satisfied then an improvement in the terms of trade will worsen the trade balance. $^{5}$ Thus, the theoretically expected effect of terms of trade on trade balance is

5 According to J Curve effect improvement in terms of trade deteriorates trade balance in the short run and improves it in the long run because export and import elasticities are low in the short run and are high in the long run. 
undetermined. The effect of foreign exchange market distortions $\left(F E M D_{t}\right)$ on trade balance is ambiguous. Distortions are theoretically expected to affect both exports and imports negatively. If its effects on imports dominate compared to its effects on exports then trade balance will improve and vice versa.

\section{Data and Model Estimation}

\subsection{Data}

Quarterly time-series data is collected for Pakistan for the period 1981/82 to 2007/08. Export (import) duty is measured as the ratio of export (import) duty revenues to the value of exports (imports). Following Sachs and Warner (1995) and Wacziarg and Welch (2003), liberalization is proxied by a dummy variable that takes the value of 1 for the period of liberalization and thereafter (in our case it is 2001 and thereafter) and 0 otherwise. ${ }^{6}$ The Unites States is taken as a foreign country. Foreign exchange market distortion is proxied by black market premium, which is difference between black market and official exchange rate expressed as percentage of the latter. All other variables are as defined previously. Variables expressed in lower case letters are in growth rates and vice versa for upper case letters. The data is taken from the International Financial Statistics, Government Finance Statistics, Pakistan Economic Survey and State Bank of Pakistan.

\subsection{Model estimation}

\subsubsection{The export model}

To examine the effects of trade liberalization on exports, an export growth model is estimated using Generalized Method of Moments (GMM) estimation technique of Arellano and Bond (1991) and Arellano (1993). GMM estimates control for potential endogeneity of the explanatory variables. The instruments used are lagged values of the explanatory variables. Table 1 provides the estimated results. Columns (1) and (2) of the table give the results of equations (4) and (5), while columns (3) and (4) give the results of the equations (6) and (7), which are basically the augmented versions of the equations (4) and (5) in which two additional explanatory variables, terms of trade $\left(t o t_{t}\right)$ and foreign exchange market distortions $\left(F E M D_{t}\right)$ have been introduced.

The results show significant price and income elasticities of demand for exports. Both the price and income elasticities are of considerable magnitudes, which confirms that the response of exports to price and income changes is in the expected direction. The export duty variable $\left(T R F_{t}^{x}\right)$, which accounts for the effects of the degree of distortions on export growth, is statistically significant, and has the expected sign. If we take the

6 Dummy variable, in fact, refers to all measures others than tariff reductions, which includes non-tariff barriers, exchange rate distortions, etc. 
estimates of column (2), for instance, the effect of a 1 percentage point reduction in export duty rate has been to raise export growth by 0.0065 percentage points. The low values of export duty coefficients show that the negative effects of the degree of trade distortion on export growth are minor, suggesting that apart from export duties, there are other factors that affect export growth, for instance, quantitative restrictions and other country specific institutional elements.

Table 1

\section{Empirical Findings of Export Growth Model}

\begin{tabular}{|c|c|c|c|c|}
\hline & \multicolumn{4}{|c|}{ Dependent variable $x_{t}$} \\
\hline & \multicolumn{2}{|c|}{ Original Specifications } & \multicolumn{2}{|c|}{ Augmented Equations } \\
\hline & (1) & (2) & (3) & (4) \\
\hline Constant & $\begin{array}{c}0.0462 \\
(5.3892)^{*}\end{array}$ & $\begin{array}{c}-0.0136 \\
(-0.5841)\end{array}$ & $\begin{array}{c}-0.0147 \\
(-0.8932)\end{array}$ & $\begin{array}{c}0.0004 \\
(0.0525)\end{array}$ \\
\hline rer $_{t}$ & $\begin{array}{c}2.8885 \\
(9.9867)^{*}\end{array}$ & $\begin{array}{c}1.2923 \\
(2.5588)^{*}\end{array}$ & $\begin{array}{c}1.1430 \\
(1.8461)^{\star *}\end{array}$ & $\begin{array}{c}0.0675 \\
(0.2248)\end{array}$ \\
\hline$y_{t}^{*}$ & $\begin{array}{c}2.0182 \\
(5.8239)^{\star}\end{array}$ & $\begin{array}{c}1.9273 \\
(2.1256)^{*}\end{array}$ & $\begin{array}{c}2.1400 \\
(3.1513)^{\star}\end{array}$ & $\begin{array}{c}1.3987 \\
(4.5154)^{\star}\end{array}$ \\
\hline$T R F_{t}^{x}$ & $\begin{array}{c}-0.0006 \\
(-2.5964)^{\star}\end{array}$ & $\begin{array}{c}-0.0065 \\
(-3.1733)^{*}\end{array}$ & $\begin{array}{c}-0.0055 \\
(-2.6811)^{\star}\end{array}$ & $\begin{array}{c}-0.0056 \\
(-4.8282)^{*}\end{array}$ \\
\hline$D_{t}$ & $\begin{array}{c}0.0041 \\
(2.4677)^{\star}\end{array}$ & $\begin{array}{c}0.0518 \\
(2.4347)^{*}\end{array}$ & $\begin{array}{c}0.0079 \\
(2.6471)^{*}\end{array}$ & $\begin{array}{c}0.0199 \\
(2.6676)^{*}\end{array}$ \\
\hline$D_{t}$ rer $_{t}$ & & $\begin{array}{c}3.2195 \\
(3.2520)^{*}\end{array}$ & & $\begin{array}{c}0.9020 \\
(1.6038)^{*}\end{array}$ \\
\hline$D_{t} y_{t}$ & & $\begin{array}{c}-3.9941 \\
(-3.5162)^{*}\end{array}$ & & $\begin{array}{c}-1.8140 \\
(-3.4966)^{*}\end{array}$ \\
\hline tot $_{t}$ & & & $\begin{array}{c}-0.7634 \\
(-10.1269)^{*}\end{array}$ & $\begin{array}{c}-0.6473 \\
(-15.1131)^{*}\end{array}$ \\
\hline FEMD $_{t}$ & & & $\begin{array}{c}-3.7878 \\
(-4.7930)^{*}\end{array}$ & $\begin{array}{c}-3.8863 \\
(-10.9725)^{\star}\end{array}$ \\
\hline$A R(1)$ & $\begin{array}{c}-0.5154 \\
(-23.8942)^{*}\end{array}$ & & & \\
\hline $\operatorname{AR}(4)$ & & $\begin{array}{c}0.5907 \\
(19.5781)^{*}\end{array}$ & $\begin{array}{c}0.5081 \\
(13.8630)^{*}\end{array}$ & $\begin{array}{c}0.5136 \\
(36.2505)^{*}\end{array}$ \\
\hline $\mathbf{R}^{2}$ & 0.4087 & 0.4878 & 0.4341 & 0.4547 \\
\hline Adjusted $\mathbf{R}^{2}$ & 0.3766 & 0.4484 & 0.3906 & 0.3996 \\
\hline DW & 2.0569 & 2.119 & 2.0620 & 2.0516 \\
\hline No. of Obs. & 98 & 99 & 99 & 99 \\
\hline
\end{tabular}

Notes: Values in parentheses denote underlying student- $t$ values. The $t$ statistics significant at $5 \%$ and $10 \%$ levels of significance are indicated by ${ }^{*}$ and ${ }^{* *}$, respectively. 
As regards the impact of reforms, trade liberalization episodes seem to have a favourable influence on export growth. The direct impact of liberalization is calculated to be 0.05 percent, which indicates that removing trade restrictions has a favourable impact on export growth in Pakistan. The low magnitude of both export duties and liberalization coefficients is perhaps not surprising because most of the major trade reforms had already taken place during the 1980s and 1990s. Column (2) also includes interaction terms defined previously. Liberalization positively affects the price elasticity and raises it by 3.22 percentage points. It implies that trade liberalization is a successful policy in Pakistan. On the other hand, the interaction variable $D_{t} y_{t}{ }^{*}$ has negative and significant coefficient (-3.99), indicating that world's income growth deteriorates Pakistan's export growth as its economy becomes more liberalized. This undesirable result is possibly because Pakistan's trade has been historically subject to supply side constraints.

The terms of trade significantly and negatively affects exports demand as was theoretically expected. It indicates that one percentage point improvement in terms of trade growth will decrease domestic exports growth by 0.76 percentage points. Similarly, foreign exchange market distortions also negatively affect export demand. Distortions perhaps have reduced the import of intermediate capital goods, which has in turn worsened export performance of the country.

\subsubsection{The import model}

The results of import growth model are reported in Table 2. Columns (1) and (2) of the table give the results of equations (9) and (10), while columns (3) and (4) give the results of the equations (11) and (12), which are the augmented versions of the equations (9) and (10), in which two additional explanatory variables, terms of trade tot $_{t}$ and foreign exchange market distortions $F E M D_{t}$ have been introduced. It is evident from the table that both the price and income elasticities of import demand are statistically different from zero and affect import growth in the expected directions. If we take the estimates of column (2), for instance, the effect of a 1 percentage point reduction in import duty rate has been to raise import growth by 0.0017 percentage points. As regard the impact of reforms, trade liberalization increases import growth by 0.01 percentage points. Thus, the results provide significant effects of import tariffs and trade liberalization on import growth in Pakistan. It is worth mentioning that the increase in import growth cannot be attributed to economic growth that liberalization promotes because the import growth equations control for domestic output growth and the endogeneity of output growth has been removed using GMM estimation.

Liberalization affects the price elasticity of demand in the expected direction, which means that as Pakistan's economy liberalizes, its import demand decreases at a higher rate with the depreciation of its currency. However, liberalization affects income elasticity in the opposite direction that is as liberalization increases, the import demand becomes less income elastic. The effect of terms of trade on import is found to be 
significant and positive as was theoretically expected. It implies that one percentage point increase in terms of trade growth will increase import growth by 0.15 percentage points. Foreign exchange market distortions negatively affect import demand as was theoretically expected and this affect is statistically significant.

Table 2

\section{Empirical Findings of Import Growth Model}

\begin{tabular}{|c|c|c|c|c|}
\hline & \multicolumn{4}{|c|}{ Dependent variable $m_{t}$} \\
\hline & \multicolumn{2}{|c|}{ Original Specifications } & \multicolumn{2}{|c|}{ Augmented Equations } \\
\hline & (1) & $(2)$ & (3) & $(4)$ \\
\hline Constant & $\begin{array}{c}0.0246 \\
(2.8188)^{*}\end{array}$ & $\begin{array}{c}0.0459 \\
(4.0138)^{*}\end{array}$ & $\begin{array}{c}0.0829 \\
(6.5549)^{*}\end{array}$ & $\begin{array}{c}0.0754 \\
(11.4631)^{\star}\end{array}$ \\
\hline$r e r_{t}$ & $\begin{array}{c}-0.9547 \\
(-10.6736)^{*}\end{array}$ & $\begin{array}{c}-0.5984 \\
(-5.5495)^{*}\end{array}$ & $\begin{array}{c}-0.5891 \\
(-7.1568)^{\star}\end{array}$ & $\begin{array}{c}-1.1121 \\
(-21.0640)^{*}\end{array}$ \\
\hline$y_{t}$ & $\begin{array}{c}0.2628 \\
(10.3168)^{*}\end{array}$ & $\begin{array}{c}0.3942 \\
(11.2726)^{*}\end{array}$ & $\begin{array}{c}0.3361 \\
(9.8703)^{*}\end{array}$ & $\begin{array}{c}0.2896 \\
(14.0364)^{*}\end{array}$ \\
\hline$T R F_{t}^{m}$ & $\begin{array}{c}-0.0012 \\
(-3.7101)^{*}\end{array}$ & $\begin{array}{c}-0.0017 \\
(-4.4533)^{*}\end{array}$ & $\begin{array}{c}-0.0025 \\
(-7.9048)^{*}\end{array}$ & $\begin{array}{c}-0.0024 \\
(-12.9145)^{*}\end{array}$ \\
\hline$D_{t}$ & $\begin{array}{c}0.0088 \\
(2.1165)^{*}\end{array}$ & $\begin{array}{c}0.0116 \\
(2.4335)^{*}\end{array}$ & $\begin{array}{c}0.0361 \\
(3.7510)^{*}\end{array}$ & $\begin{array}{c}0.0278 \\
(8.1335)^{*}\end{array}$ \\
\hline$D_{t}$ rer $_{t}$ & & $\begin{array}{c}-0.6087 \\
(-3.9331)^{*}\end{array}$ & & $\begin{array}{c}-0.4382 \\
(-8.1695)^{*}\end{array}$ \\
\hline$D_{t} y_{t}$ & & $\begin{array}{c}-0.2101 \\
(-4.0649)^{*}\end{array}$ & & $\begin{array}{c}0.0413 \\
(1.3557)\end{array}$ \\
\hline tot $_{t}$ & & & $\begin{array}{c}0.0097 \\
(0.1920)\end{array}$ & $\begin{array}{c}0.1498 \\
(8.0589)^{*}\end{array}$ \\
\hline$F E M D_{t}$ & & & $\begin{array}{c}-2.7436 \\
(-6.4915)^{\star}\end{array}$ & $\begin{array}{c}-2.9307 \\
(-16.3691)^{*}\end{array}$ \\
\hline $\operatorname{AR}(2)$ & & & & $\begin{array}{c}0.0122 \\
(1.6195)^{\star *}\end{array}$ \\
\hline $\operatorname{AR}(4)$ & $\begin{array}{c}0.2658 \\
(20.0427)^{*}\end{array}$ & & $\begin{array}{c}0.0472 \\
(3.2973)^{*}\end{array}$ & \\
\hline $\mathbf{R}^{2}$ & 0.3405 & 0.2624 & 0.3026 & 0.2931 \\
\hline Adjusted $\mathrm{R}^{2}$ & 0.3051 & 0.2143 & 0.2490 & 0.2216 \\
\hline DW & 2.4288 & 2.3758 & 2.0556 & 2.3448 \\
\hline No. of Obs. & 99 & 99 & 99 & 99 \\
\hline
\end{tabular}

Notes: Values in parentheses denote underlying student- $t$ values. The $t$ statistics significant at $5 \%$ and $10 \%$ levels of significance are indicated by * and ${ }^{* *}$, respectively. 


\subsubsection{Effects of liberalization on export and import growth: a comparison}

Here we compare the effects of trade liberalization on export and import growths to see its effects on trade balance. The comparison is shown in Table 3 . The effect of duty reductions is slightly greater on export growth than on import growth. However, trade liberalization has increased import growth more than export growth. This indicates that trade liberalization has deteriorated trade balance in Pakistan. ${ }^{7}$

Liberalization has decreased the income elasticities of demand for exports and imports with the greater effect on the former than on the latter. It has increased the price elasticity of demand for exports and decreased the price elasticity of demand for imports. From the volume effects on trade, therefore, the presumption is that the effect of trade liberalization on trade balance is ambiguous. One may conclude from the table that this would be prima facie evidence that both income and price adjustments are necessary to keep the trade balance at a sustainable level. The contrast between the performance of exports and imports suggests that trade liberalization has significant effects on trade balance. In the next section we attempt to estimate these effects.

Table 3

Comparison of the Effects of Trade Liberalization on Export and Import Growths

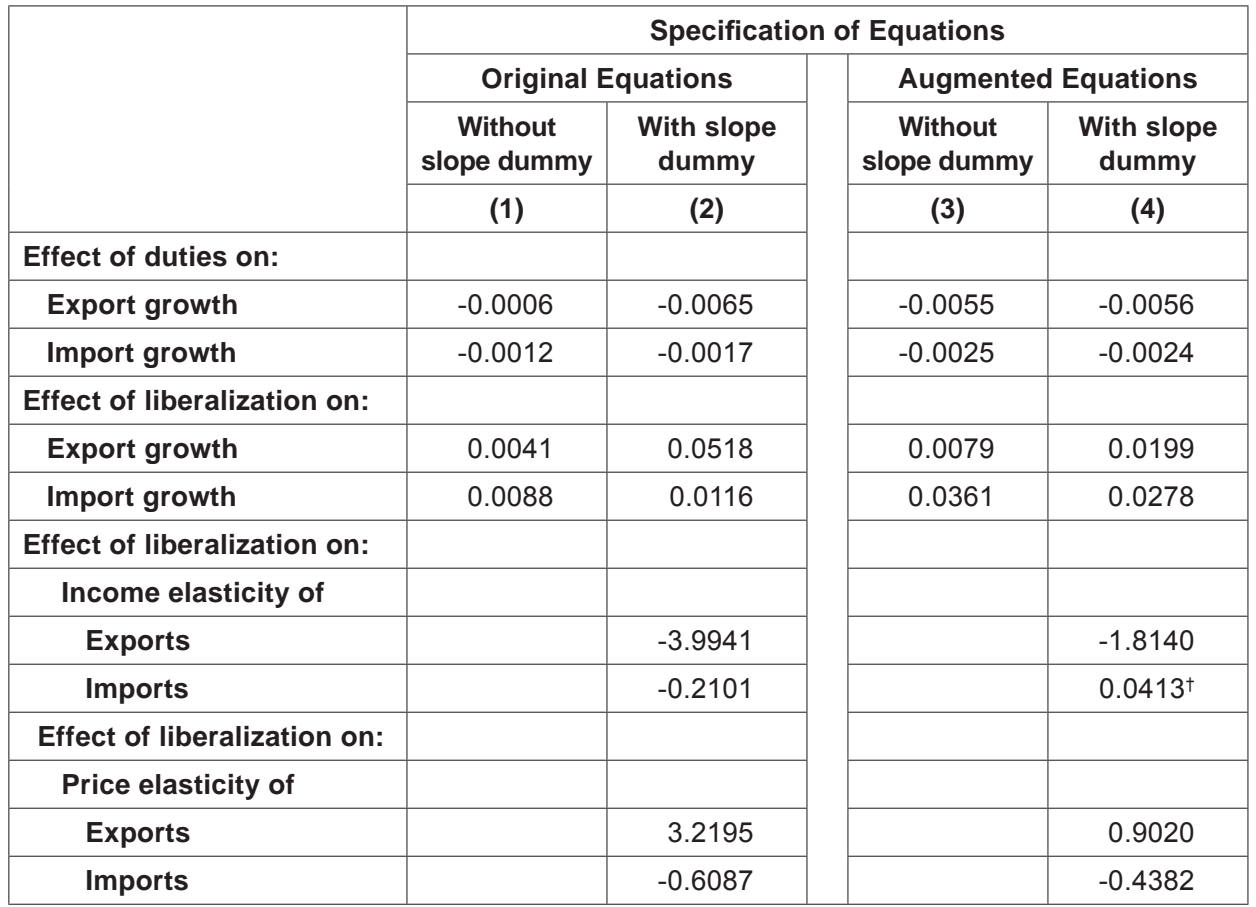

Note: $†$ denotes that the estimated coefficient is not significant at 5 and/or $10 \%$ level of significance.

7 Trade liberalization can also lead to non-monotonic adjustments in the trade balance. Further research needs to be carried out to check whether there is such non-monotonicity for Pakistan. For details on the phenomenon interested readers are referred to Dornbusch (1992). 
Table 4

Empirical Findings of Trade Balance Growth Model

\begin{tabular}{|c|c|c|c|c|}
\hline & \multicolumn{4}{|c|}{ Dependent variable $t b_{t}$} \\
\hline & \multicolumn{2}{|c|}{ Original Specifications } & \multicolumn{2}{|c|}{ Augmented Equations } \\
\hline & (1) & (2) & (3) & (4) \\
\hline Constant & $\begin{array}{c}0.022 \\
(1.606)^{* *}\end{array}$ & $\begin{array}{c}-0.060 \\
(-2.031)^{*}\end{array}$ & $\begin{array}{c}-0.0976 \\
(-4.5656)^{*}\end{array}$ & $\begin{array}{c}-0.0750 \\
(-7.2961)^{*}\end{array}$ \\
\hline$r e r_{t}$ & $\begin{array}{c}3.843 \\
(14.428)^{*}\end{array}$ & $\begin{array}{c}1.891 \\
(2.374)^{\star}\end{array}$ & $\begin{array}{c}1.7322 \\
(2.9122)^{\star}\end{array}$ & $\begin{array}{c}1.1796 \\
(3.7567)^{*}\end{array}$ \\
\hline$y_{t}^{*}$ & $\begin{array}{c}2.018 \\
(5.824)^{*}\end{array}$ & $\begin{array}{c}1.927 \\
(2.126)^{\star}\end{array}$ & $\begin{array}{c}2.1400 \\
(3.1513)^{\star}\end{array}$ & $\begin{array}{c}1.3987 \\
(4.5154)^{*}\end{array}$ \\
\hline$y_{t}$ & $\begin{array}{c}-0.263 \\
(-10.317)^{*}\end{array}$ & $\begin{array}{c}-0.394 \\
(-11.273)^{*}\end{array}$ & $\begin{array}{c}-0.3361 \\
(-9.8703)^{*}\end{array}$ & $\begin{array}{c}-0.2896 \\
(-14.0364)^{*}\end{array}$ \\
\hline$T R F_{t}^{x}$ & $\begin{array}{c}-0.001 \\
(-2.596)^{\star}\end{array}$ & $\begin{array}{c}-0.007 \\
(-3.173)^{*}\end{array}$ & $\begin{array}{c}-0.0055 \\
(-2.6811)^{*}\end{array}$ & $\begin{array}{c}-0.0056 \\
(-4.8282)^{*}\end{array}$ \\
\hline$T R F_{t}^{m}$ & $\begin{array}{c}0.001 \\
(3.710)^{*}\end{array}$ & $\begin{array}{c}0.002 \\
(4.453)^{*}\end{array}$ & $\begin{array}{c}0.0025 \\
(7.9048)^{*}\end{array}$ & $\begin{array}{c}0.0024 \\
(12.9145)^{\star}\end{array}$ \\
\hline$D_{t}$ & $\begin{array}{c}-0.005 \\
(-2.465)^{\star}\end{array}$ & $\begin{array}{c}0.040 \\
(2.505)^{\star}\end{array}$ & $\begin{array}{c}-0.0282 \\
(-1.8159)^{\star *}\end{array}$ & $\begin{array}{c}-0.0078 \\
(-0.9075)\end{array}$ \\
\hline$D_{t}$ rer $_{t}$ & & $\begin{array}{c}3.828 \\
(3.965)^{\star}\end{array}$ & & $\begin{array}{c}1.3402 \\
(2.2673)^{\star}\end{array}$ \\
\hline$D_{t} y_{t}^{*}$ & & $\begin{array}{c}-3.994 \\
(-3.516)^{\star}\end{array}$ & & $\begin{array}{c}-1.8140 \\
(-3.4966)^{\star}\end{array}$ \\
\hline$D_{t} y_{t}$ & & $\begin{array}{c}0.210 \\
(4.065)^{*}\end{array}$ & & $\begin{array}{c}-0.0413 \\
(-1.3557)\end{array}$ \\
\hline tot $_{t}$ & $\begin{array}{l}1 \\
- \\
\end{array}$ & $\begin{array}{l}1 \\
- \\
\end{array}$ & $\begin{array}{c}0.2269 \\
(3.1397)^{*}\end{array}$ & $\begin{array}{c}0.2029 \\
(5.1806)^{\star}\end{array}$ \\
\hline$F E M D_{t}$ & & & $\begin{array}{c}-1.0442 \\
(-1.3652)\end{array}$ & $\begin{array}{c}-0.9556 \\
(-3.9118)^{*}\end{array}$ \\
\hline $\operatorname{AR}(1)$ & $\begin{array}{c}-0.515 \\
(-23.894)^{\star}\end{array}$ & & & \\
\hline$A R(2)$ & & & & $\begin{array}{c}-0.0122 \\
(-1.6195)^{\star *}\end{array}$ \\
\hline $\operatorname{AR}(4)$ & $\begin{array}{c}-0.266 \\
(-20.043)^{*}\end{array}$ & $\begin{array}{c}0.591 \\
(19.578)^{*}\end{array}$ & $\begin{array}{c}0.4608 \\
(12.9226)^{*}\end{array}$ & $\begin{array}{c}0.5136 \\
(36.2505)^{*}\end{array}$ \\
\hline $\mathbf{R}^{2}$ & 0.252 & 0.280 & 0.2687 & 0.3822 \\
\hline Adjusted $\mathbf{R}^{2}$ & 0.230 & 0.260 & 0.2451 & 0.3550 \\
\hline DW & 1.792 & 2.031 & 2.0226 & 2.0729 \\
\hline No. of Obs. & 99 & 99 & 99 & 99 \\
\hline
\end{tabular}

Notes: Values in parentheses denote underlying student-t values. The t statistics significant at $5 \%$ and $10 \%$ levels of significance are indicated by ${ }^{*}$ and ${ }^{* *}$, respectively. 


\subsubsection{The trade balance model}

Table 4 gives the results of trade balance growth models shown in equations 15 to 18 . It is evident from the table that the estimated coefficients of relative price changes and foreign and domestic income growth rates all have the expected signs and they all are statistically different from zero. The positive effect of world income growth on trade balance is greater than the negative effect of domestic income growth on trade balance. Reduction of export duties improves trade balance, while the reduction of import duties deteriorates the trade balance. The pure effect of trade liberalization on trade balance is negative. This result confirms that liberalization episodes of the 1980s and $1990 \mathrm{~s}$ have affected the trade balance adversely. The positive sign of $D_{t}$ rer $_{t}$ shows that liberalization has made trade sector more flexible and hence to respond more actively to change in real exchange rate. The negative sign of $D_{t} y_{t}{ }^{*}$ stipulates that after liberalization growth of foreign income has worsened the growth of domestic trade balance by 3.99 percentage points. The positive sign on $D_{t} y_{t}$ indicates that after liberalization growth of domestic income has deteriorated the trade balance by a further 0.21 percentage points. Terms of trade significantly and positively affect growth of trade balance while foreign exchange market distortions significantly and negatively affect growth of trade balance.

\section{Conclusion}

In the 1980s Pakistan started trade liberalization process by reducing export and import duties and eliminating quantitative restrictions. This liberalization process has affected various sectors of the economy, in which exports, imports and trade balance are the most important sectors. The paper empirically examines the effects of trade liberalization on exports, imports and trade balance in Pakistan using data for the period $1981 / 82$ to $2007 / 08$. The estimated results obtained are strong and robust to alternative model specifications. Elimination of export and import duties has significantly affected growth of exports and imports in Pakistan with the impact on imports being greater than on exports. Similarly, pure effect of trade liberalization is to raise import growth more than export growth. Thus, trade liberalization has worsened trade balance in Pakistan. This result is consistent with the results of previous studies that in developing countries trade liberalization deteriorates trade balance in the short run. It means that the balance of payments consequences of trade liberalization matter in Pakistan. Parameter estimates of relative price changes, domestic and foreign income, terms of trade and foreign exchange market distortions fall within the boundaries found in the previous empirical literature. These variables are found to affect exports, imports and trade balance in the theoretically expected directions in most of the estimations and, in general, are statistically significant. Further, inclusion of interaction terms indicates that liberalization stimulates both price and income elasticities of exports, imports and trade balance. 
The estimated models have some policy relevance for policy makers in Pakistan. The balance of payments crises have shown that output growth has been thwarted in Pakistan by its balance of payments positions. Further, trade openness policies in Pakistan have not been complemented with export promotion plans, which could provide valuable foreign exchange for higher imports originated mainly by liberalization policies. An important policy implication therefore is that Pakistan should liberalize its exports and imports in such a manner that a balance is achieved between exports and imports. More work is needed, however, to assess the impact of trade liberalization on trade balance by estimating disaggregated export and import models. Another extension of this research might be to focus on Pakistan's trading partners and the particular commodities traded. There is also need to draw some attention on two new directions in trade strategy in Pakistan that is trade liberalization in services sector and regional free trade agreements.

\section{References}

Agosin, M. R. (1991), "Trade Policy Reform and Economic Performance: A Review of the Issues and Some Preliminary Evidence.” UNCTAD Discussion Paper No. 1991(41), Geneva.

Ahmed, N. (2000), "Export Response to Trade Liberalization in Bangladesh: A Cointegration Analysis." Applied Economics, Vol. 32, pp. 1077-84.

Arellano, M. (1993), "On Testing of Correlation Effects with Panel Data." Journal of Econometrics, Vol. 59, No. 1, pp. 87-97.

Arellano, M., Bond S. (1991), "Some Tests of Specification for Panel Data: Monte Carlo Evidence and an Application to Employment Equations." Review of Economic Studies, Vol. 58, No. 2, pp. 277-97.

Bertola, G., Faini R. (1991), "Import Demand and Non-Tariff Barriers: The Impact of Trade Liberalization." Journal of Development Economics, Vol. 34, No. 1-2, pp. 269-86.

Bleaney, M. (1999), "Trade Reform, Macroeconomic Performance and Export Growth in Ten Latin American Countries, 1979-95." Journal of International Trade and Economic Development, Vol. 8, No.1, pp. 89-105.

Greenaway, D., Sapsford D. (1994), "What Does Liberalisation Do for Exports and Growth." Review of World Economics, Vol. 30, pp. 157-74.

Jenkins, R. (1996), "Trade Performance and Export Performance in Bolivia." Development and Change, Vol. 27, pp. 693-716.

Ju, J., Y. Wu, Zeng L. (2010), "The Impact of Trade Liberalization on the Trade Balance in Developing Countries." IMF Staff Papers, Vol. 57, No. 2, pp. 427-49

Khan, M. S., Zahler R. (1985), "Trade and Financial Liberalisation Given External Shocks and Inconsistent Domestic Policies." IMF Staff Papers, Vol. 32, No. 1, pp. 22-55.

Krueger, A. O. (1978), "Liberalisation Attempts and Consequences, Liberalisation, Direction of Bias and Economic Growth." Foreign Trade Regimes and Economic Development, Vol. 10, pp. 277-300.

Mah, J. S. (1999), "Import Demand Liberalization and Economic Development." Journal of Policy Modeling, Vol. 21, No. 4, pp. 497-503.

Melo, O., Vogt M. G. (1984), "Determinants of the Demand for Imports of Venezuela." Journal of Development Economics, Vol. 14, pp. 351-58.

Ostry, J. D., Rose A. K. (1992), "An Empirical Evaluation of the Macroeconomic Effects of Tariffs." Journal of International Money and Finance, Vol. 11, No. 1, pp. 3-79. 
Pacheco-López, P. (2003), "The Impact of Trade liberalisation on the Trade Balance, the Balance of Payments and Economic Growth: the Case of Mexico." (Draft Available at http://www.etsg.org/ ETSG2003/papers/pacheco-lopez.pdf)

Pacheco-Lopez, P. (2005), "The Impact of Trade Liberalization on Exports, Imports, the Balance of Payments and Growth: The Case of Mexico." Journal of Post Keynesian Economics, Vol. 27, No. 4, pp. 595-619.

Sachs, J. D., Warner A. M. (1995), "Economic Reform and the Process of Global Integration." Brookings Papers on Economic Activity, Vol. 1, pp. 1-118.

Santos-Paulino, A., Thirlwall A. P. (2004), "The Impact of Trade Liberalisation on Exports, Imports, and the Balance of Payments of Developing Countries." Economic Journal, Vol. 114, No. 1, pp. F50-F72.

Santos-Paulino, A. U. (2002a), "Trade Liberalisation and Export Performance in Selected Developing Countries." Journal of Development Studies, Vol. 39, No.1, pp. 140-64.

Santos-Paulino, A. U. (2002b), "The Effects of Trade Liberalisation on Imports in Selected Developing Countries." World Development, Vol. 30, No. 6, pp. 959-74.

Santos-Paulino, A. U. (2004), 'Trade Liberalisation and the Balance of Payments in Selected Developing Countries." Manchester School, Vol. 71, No. 1, pp. 100-18.

Shafaedin, S. M. (1994), "The Impact of Trade Liberalisation on Exports and GDP in Least Developed Countries.” UNCTAD Discussion Paper No. 1994 (85), Geneva.

Wacziarg, R., Welch K. H. (2003), "Trade Liberalization and Growth: New Evidence." NBER Working Paper No. 2003 (10152), Cambridge Mass.

Weiss, J. (1992), "Export Response to Trade-Reforms: Recent Mexican Experience." Development Policy Review, Vol. 10, No.1, pp. 43-60. 